\title{
Carta de Apresentação aos Leitores
}

O número 18 do periódico Revista Brazilian Journal of Latin American Studies/Cadernos Prolam-USP apresenta, em seus quatro primeiros artigos, um dossiê acerca do Pensamento Político e Econômico Latino Americano. O tema foi selecionado por sua constituição interdisciplinar, que imbrica história, política, economia e cultura, apresentando-se como imprescindível para a compreensão da formação social e construção da identidade regional. O conjunto de quatro artigos, longe de ser exaustivo, permite identificar algumas correntes que impactaram o processo de construção das nações latinoamericanas e que, mesmo após séculos, ainda influenciam os países desse complexo continente.

A primeira apresentação é sobre José Martí e sua visão acerca do progresso e do materialismo histórico, na qual o autor, Fabio Luís Barbosa dos Santos realiza uma apreciação crítica da visão de Martí, relacionando suas premissas ideológicas com a leitura que faz sobre Marx, o socialismo e a proposta de haver um projeto nacional para Cuba.

O segundo artigo, de autoria de Márcio Bobik Braga, traz uma síntese do pensamento político e econômico do intelectual argentino Juan Batista Alberdi, um pensador que buscou compreender seu país em um momento histórico de construção institucional. Com base na análise de duas das principais obras de Alberdi, o autor destaca algumas questões fundamentais no processo de formação política e econômica da própria América Latina.

O terceiro artigo trata de uma discussão teórico-política sobre três variantes de poder, identificando pontos de aproximação e distinção entre bolivarianismo, caudilhismo e populismo. De autoria de Francisco Mata Machado Tavares apresenta uma relação entre o personalismo político e a afirmação de autonomia subcontinental.

Por fim, o quarto artigo trata de uma comparação entre ideias de dois dos principais atores-pensadores sobre a América Latina: Simón Bolívar e José Martí. De autoria de Rita de Cássia Marques Lima de Castro, o texto realiza a compilação e a comparação de cartas e obras de Bolívar e Martí, buscando analisar a independência da América Latina em suas estruturas primárias - as ideias desses libertadores que reverberam até hoje no continente.

Embora componham este dossiê, os artigos passaram, conforme procedimento usual da revista, por dupla arbitragem anônima.

A segunda parte do número 18 apresenta diversas temáticas, todas relacionadas à América Latina, seguindo o propósito e a linha editorial da revista que pauta pela interdisciplinaridade e pluralidade de abordagens, reforçando o papel de contribuir para a construção da identidade latinoamericana.

Boa leitura!

Os Editores 